\title{
Pengaruh Fungi Mikoriza Arbuskula Indigen Terhadap Kerapatan Gulma, Pertumbuhan dan Produksi Jagung Manis (Zea mays saccharata (Sturt.) Bailey)
}

\author{
HALIM ${ }^{1}$, MAKMUR J. ARMA ${ }^{1}$, FRANSISCUS S. REMBON ${ }^{2}$, RESMAN $^{2}$ \\ ${ }^{1}$ Jurusan Agroteknologi, Fakultas Pertanian Universitas Halu Oleo, Jln. H.E.A Mokodompit, Kendari Sulawesi Tenggara \\ 2 Jurusan Ilmu Tanah, Fakultas Pertanian Universitas Halu Oleo, Jln. H.E.A Mokodompit,Kendari Sulawesi Tenggara \\ Diterima: 09 November 2019 - Disetujui: 05 Juni 2020 \\ (C) 2020 Jurusan Biologi FMIPA Universitas Cenderawasih
}

\begin{abstract}
This study aims to determine the effect of local arbuscular mycorrhizal fungi (AMF) on weed density, growth and yield of sweet corn in marginal soils. This study used a randomized block design with local AMF propagules which consisted of 4 levels: $0 \mathrm{~g} /$ planting hole or control $\left(\mathrm{A}_{0}\right), 15 \mathrm{~g} /$ planting hole $\left(\mathrm{A}_{1}\right), 30 \mathrm{~g} /$ planting hole $\left(\mathrm{A}_{2}\right)$ and $45 \mathrm{~g} /$ planting hole $\left(\mathrm{A}_{3}\right)$. The research parameters observed were: weed density, plant height, stem diameter, crop yield, and the percentage of AMF infection in the roots of corn plants. The results showed that the highest weed dominance value at the age of 14 DAP was Cyperus rotundus as $36.8 \%$ in treatment of AMF $45 \mathrm{~g} /$ planting hole $\left(\mathrm{A}_{3}\right)$, age 56 DAP the highest weed dominance value was Hyptis capitata as $47.1 \%$ in the treatment of AMF $30 \mathrm{~g} / \mathrm{planting}$ hole. The best plant height and stem diameter were found in the treatment of AMF $45 \mathrm{~g} /$ planting holes $\left(\mathrm{A}_{3}\right)$ at 56 DAP, the average plant height reached $234.05 \mathrm{~cm}$ and the average stem diameter reached $3.72 \mathrm{~cm}$. Increased production of corn plants that were given local AMF ranged from 2.70 to 3.10 tons ha ${ }^{-1}$ or an average increase in overall corn crop production of 2.86 tons ha-1. The average percentage of mycorrhiza fungi infections in the highest roots of corn plants in the treatment of AMF $45 \mathrm{~g} /$ planting hole $\left(\mathrm{A}_{3}\right)$ as $94 \%$.
\end{abstract}

Key words: Arbuscular mycorrhiza fungi; vesicles; hypha; maize; ultisols.

\section{PENDAHULUAN}

Jagung merupakan salah satu tanaman serealia yang tumbuh hampir di seluruh dunia dan tergolong spesies dengan variabilitas genetik yang besar dan dapat menghasilkan genotipe baru yang dapat beradaptasi terhadap berbagai karakteristik lingkungan. Menurut Nugroho (2009) di Indonesia jagung merupakan bahan makanan pokok kedua setelah padi. Hal ini diperkuat oleh pernyataan Hayati et al. (2019), bahwa jagung merupakan salah satu komodi

\footnotetext{
* Alamat korespondensi:

Jurusan Agroteknologi, Fakultas Pertanian Universitas Halu Oleo, Kendari, Indonesia. HP :+6285221269054.

Email: haliwu_lim73@yahoo.co.id
}

pangan dan menjadi makanan pokok pada beberapa wilayah di Indonesia.

Kendala utama yang dihadapi oleh masyarakat dalam meningkatkan produksi tanaman jagung adalah kondisi tanah yang didominasi oleh jenis tanah marginal, dengan tingkat kesuburan tanah yang rendah, miskin bahan organik, kandungan unsur hara yang sangat rendah terutama nitrogen $(\mathrm{N})$, fosfor $(\mathrm{P})$, kalium (K), magnesium $(\mathrm{Mg}), \mathrm{pH}$ rendah, kejenuhan aluminium (Al) tinggi serta tingkat pertukaran basa yang rendah. Hasil Penelitian Halim \& Rembon (2013), menunjukkan bahwa kandungan tanah ultisol daerah Abenggi menunjukkan $\mathrm{pH}$ 5,77, bahan organik 1,92\%, nitrogen $0,17 \%$, fosfor 12,75 ppm serta kalium 0,22 me/100 g. Begitu pula pada tanah ultisol Sindang Kasih yaitu $\mathrm{pH} 4,9$, bahan organik 4,80\%, nitrogen 
0,15\%, fosfor 17,88 ppm serta kalium 0,29 me/100 g (Halim \& Resman, 2011). Kondisi tanah yang demikian dapat mengakibatkan kurang optimalnya produksi tanaman jagung yang secara langsung dapat mempengaruhi tingkat pendapatan petani pada akhir masa tanam. Penyebab lain rendahnya produksi tanaman jagung adalah adanya kompetisi antara tanaman dengan gulma. Hasil penelitian Hartzler \& Pringnitz (2005) menunjukkan penurunan hasil tanaman jagung akibat kompetisi dengan gulma antara 25-50\%. Namun demikian, jika gulma dapat dikelola dengan baik maka mampu memberikan fungsi bagi kehidupan mikroorganisme yang berasosiasi dengan perakaran gulma (Halim, 2010). Salah satu mikroorganisme yang berasosiasi dengan perakaran gulma adalah fungi mikoriza (Halim, 2009).

Fungi mikoriza berperan dalam meningkatkan kapasitas tanaman terhadap unsur hara dan $\mathrm{CO}_{2}$, mampu memperluas permukaan area serapan unsur hara dan $\mathrm{CO}_{2}$ pada tanahtanah yang kurang subur (Talanca, 2010), mampu berkompetisi dengan gulma (Halim, 2010), dapat melindungi akar tanaman dari serangan patogen tular tanah (Halim et al., 2016), meningkatkan resistensi tanaman terhadap kekeringan, hifa fungi mikoriza mampu menyerap air pada pori-pori tanah yang tidak bisa ditembus oleh perakaran tanaman (Santoso, 2007) serta menggantikan sekitar 50\% kebutuhan fosfat tanaman, 40\% nitrogen dan 25\% kalium (Setiadi, 1996).

Fungi mikoriza berperan penting dalam penyerapan unsur hara terutama fosfor. Secara umum diketahui bahwa kolonisasi fungi mikoriza mampu meningkatkan pertumbuhan tanaman melalui peningkatan penyerapan hara. Selain itu, kolonisasi dapat memperluas permukaan serapan yang berdampak pada mobilisasi sumber hara yang tak mudah tersedia atau dapat juga dengan cara ekskresi senyawa khelat (Delvian, 2005). Unsur hara utama yang diserap adalah fosfor (P), nitrogen $(\mathrm{N})$ kalium $(\mathrm{K})$ dan unsur mikro lain seperti Ca, Mg, Na, K, dan Al (Subowo et al., 1996). Melalui proses enzimatik, unsur hara yang terikat kuat dalam ikatan senyawa kimia seperti aluminium (Al) dan besi (Fe) dapat diuraikan dan dipecahkan sehingga menjadi tersedia bagi tanaman (Santoso, 2007). Hasil penelitian Halim (2009), bahwa aplikasi propagul fungi mikoriza indigen gulma pada dosis 1 ton ha ${ }^{-1}$ mampu meningkatkan produksi tanaman jagung sampai 10 ton ha-1 pada tanah ultisol. Penelitian ini bertujuan untuk mengetahui pengaruh fungi mikoriza lokal terhadap kepadatan gulma, pertumbuhan dan hasil tanaman jagung manis pada tanah marginal.

\section{METODE PENELITIAN}

\section{Tempat dan Waktu Penelitian}

Penelitian ini dilaksanakan di Desa RambuRambu Jaya Kecamatan Ranomeeto Barat Kabupaten Konawe Selatan Provinsi Sulawesi Tenggara dan Laboratorium Fakultas Kehutanan dan Ilmu Lingkungan Universitas Halu Oleo pada bulan Desember 2018 sampai dengan bulan Juni 2019.

\section{Alat dan Bahan}

Alat-alat yang digunakan yaitu: alat tulis, meteran, kamera digital, timbangan digital, mikroskop okuler/bikuler, cangkul, parang, kuadran (ukuran $50 \times 50 \mathrm{~cm}$ ) serta saringan dari baja dengan berbagai ukuran mesh $(500,250,90$, dan $50 \mu \mathrm{m})$.

Bahan-bahan yang digunakan dalam penelitian ini adalah: bibit jagung manis hibrida (Bonanza F1), tali nilon, air steril, tanah steril, propagul FMA indigen, pupuk bokashi, polibag $(20 \times 30 \times 40 \mathrm{~cm})$, air steril, sukrosa $30 \%$, formalin aceto-alkohol (FAA), larutan $\mathrm{KOH} 10 \%$, larutan hidrogen peroksida alkali $10 \%\left(\mathrm{H}_{2} \mathrm{O}_{2}\right)$, larutan $\mathrm{HCl}$ $1 \%$, zat pewarna carbol fuchin $0,05 \%$, laktogliserol, kertas saring, amplop mail, serta kertas label.

\section{Cara Kerja}

Pengolahan tanah diawali dengan pembersihan vegetasi sekunder yang tumbuh pada lahan yang dijadikan sebagai lokasi penelitian. Pada pengolahan tanah yang pertama dilakukan menggunakan cangkul dengan 
kedalaman $\pm 30 \mathrm{~cm}$, selanjutnya dilakukan pengolahan tanah yang kedua untuk memecahkan bongkahan-bongkahan tanah dan meratakan tanah. Setelah itu, dilanjutkan pembuatan petakpetak percobaan dengan ukuran setiap petak $4 \mathrm{~m}$ x $3 \mathrm{~m}$, jarak antar kelompok $1 \mathrm{~m}$, jarak antar perlakuan $50 \mathrm{~cm}$. Setiap petak terdiri dari 35 tanaman. Benih jagung ditanam dengan menggunakan tugal kedalaman lubang tanam 5 $\mathrm{cm}$, tiap lubang sebanyak 2 biji. Benih yang ditanam adalah jagung manis dengan jarak tanam $70 \mathrm{~cm} \times 30 \mathrm{~cm}$. Sumber propagul FMA yang digunakan dalam penelitian merupakan koleksi dari Halim (2009) yang diisolasi dari gulma Chromolaena odorata. Sebelum digunakan FMA tersebut terlebih dahulu diperbanyak pada tanaman jagung (Halim, 2018), dengan tingkat persentase infeksi pada perakaran tanaman inang berkisar antara 90-100\% (Betty et al., 2002), dengan kepadatan spora berkisar antara 70-100 spora/30 g media kultur (Delvian, 2006). Aplikasi propagul FMA dilakukan bersamaan waktunya dengan penanaman jagung. Letak propagul FMA berada di bawah benih jagung (Halim, 2009).

Penelitian ini menggunakan rancangan acak kelompok (RAK) dengan perlakuan propagul fungi mikoriza arbuskula (FMA) indigen yang terdiri atas 4 taraf yaitu: tanpa FMA/lubang tanam atau kontrol $\left(\mathrm{A}_{0}\right)$, FMA 15 gram/lubang tanam $\left(\mathrm{A}_{1}\right)$, FMA 30 gram/lubang tanam $\left(\mathrm{A}_{2}\right)$ dan FMA 45 gram/lubang tanam $\left(\mathrm{A}_{3}\right)$ dengan 3 ulangan, sehingga terdapat 12 unit percobaan.

Tabel 1. Nilai jumlah dominansi gulma pada umur 14 HST.

\begin{tabular}{llcccc}
\hline No. Jenis gulma & \multicolumn{3}{c}{ Perlakuan } & $\mathrm{A}_{2}$ & $\mathrm{~A}_{3}$ \\
\cline { 3 - 5 } & & $\mathrm{A}_{0}$ & 0,9 & 0,0 & 0,0 \\
\hline 1. & Blumea lacera (Burm.f.) DC & 0,0 & 0,9 & 0,0 & 2,6 \\
2. & Borreria alata (Aubl.) DC & 3,0 & 11,9 & 11,1 & 9,2 \\
3. & Borreria repens DC & 51,5 & 14,7 & 11,1 & 13,2 \\
4. & Cyperus sp. & 6,1 & 0,0 & 0,0 & 0,0 \\
5. & Cyperus iria L. & 3,0 & 11,9 & 2,2 & 3,9 \\
6. & Cyperus kyllingia Endl & 0,0 & 14,7 & 22,2 & 36,8 \\
7. & Cyperus rotundus L. & 9,1 & 0,0 & 2,6 \\
8. & Eriocaulon heterolepis Steud. & 0,0 & 0,0 & 0,0 \\
9. & Eupatorium odorata L. & 0,0 & 2,8 & 0,0 & 0,0 \\
10. & Fimbristylis acuminate Vahl & 0,0 & 0,0 & 0,0 & 1,3 \\
11. & Glinus lotoides L. & 0,0 & 2,8 & 0,0 & 0,0 \\
12. & Hedyotis corymbosa (L.) Lamk & 0,0 & 1,8 & 15,6 & 11,8 \\
13. & Hedyotis diffusa Wild & 0,0 & 11,9 & 8,9 & 6,6 \\
14. & Hyptis capitata Jacq & 18,2 & 7,3 & 8,9 & 2,6 \\
15. & Imperata cylindrica L. & 0,0 & 9,2 & 0,0 & 0,0 \\
16. & Lindernia antipoda (L.) Alston & 0,0 & 0,9 & 0,0 & 0,0 \\
17. & Lindernia crustacea (L.) F.v.M. & 0,0 & 0,0 & 4,4 & 0,0 \\
18. & Lindernia sp. & 9,1 & 0,0 & 3,0 \\
19. & Ludwigia hyssopifolia (G.Don) Exell & 0,0 & 1,8 & 0,0 \\
20. & Ludwigia octovalvis (Jacq) Raven & 0,0 & 0,0 & 0,0 & 0,0 \\
21. & Paspalum conjugatum Berg & 0,0 & 1,8 & 8,9 & 0,0 \\
22. & Phyllanthus niruri (Auct) & 0,0 & 0,0 & 0,0 & 3,9 \\
23. & Scoparia dulcis L. & 0,0 & 2,8 & 0,0 & 1,3 \\
24. & Sonchus arvensis L. & 0,0 & 0,0 & 0,0 & 0,0 \\
25. & Torenia violacea (Azaola) Pennell & 0,0 & 1,8 & 2,2 & 0,0 \\
\hline & & 100 & 99,9 & 99,9 & 99,7 \\
\hline
\end{tabular}


Pemeliharaan di lapangan meliputi: yaitu nilai penting dibagi jumlah besaran. penyulaman, penjarangan, pemupukan dan Pengamatan dilakukan sebanyak dua kali yaitu penyiangan. Penyulaman dan penjarangan pada umur 14 HST dan 56 HST dengan dilakukan 7 HST dengan maksud untuk menggunakan rumus yang dikemukakan oleh memperoleh keseragaman tanaman. Pemupukan dilakukan 14 hari sebelum tanam menggunakan pupuk organik (kotoran sapi) dengan dosis 6 $\mathrm{kg} /$ petak (setara 15 ton ha-1). Penyiangan gulma dilakukan pada umur 14 dan 28 HST dengan cara memotong bagian atas gulma, sehingga tidak mengganggu perakaran tanaman dan hifa FMA dalam tanah.

\section{Parameter Penelitian}

Parameter yang diamati dalam penelitian ini adalah: Nisbah Jumlah Dominansi (NJD) gulma (Chaves \& Bhadanari, 1982):

$$
\begin{aligned}
& \text { Kerapatan relatif }=\frac{\text { jumlah individu suatu jenis }}{\text { jumlah seluruh individu }} \times 100 \% \\
& \text { Dominansi relatif }=\frac{\text { dominansi suatu jenis }}{\text { dominansi seluruh jenis }} \times 100 \%
\end{aligned}
$$

Frekuensi relatif $=\frac{\text { frekuensi suatu jenis }}{\text { jumlah frekuensi seluruh jenis }} \times 100 \%$

Nilai penting suatu jenis $=$ Kerapatan Relatif+Frekuensi Relatif +Dominansi Relatif.

\begin{tabular}{|c|c|c|c|c|c|}
\hline \multirow[t]{2}{*}{ No. } & \multirow[t]{2}{*}{ Jenis gulma } & \multicolumn{4}{|c|}{ Perlakuan } \\
\hline & & $\mathrm{A}_{0}$ & $\mathrm{~A}_{1}$ & $\mathrm{~A}_{2}$ & $\mathrm{~A}_{3}$ \\
\hline 1. & Blumea lacera (Burm.f.) DC & 0,0 & 0,0 & 0,0 & 1,8 \\
\hline 2. & Borreria alata (Aubl.) DC & 0,0 & 2,2 & 11,8 & 7,1 \\
\hline 3. & Borreria repens DC & 6,3 & 28,9 & 11,8 & 23,2 \\
\hline 4. & Cyperus sp. & 8,3 & 8,9 & 0,0 & 10,7 \\
\hline 5. & Cyperus iria L. & 0,0 & 0,0 & 0,0 & 0,0 \\
\hline 6. & Cyperus kyllingia Endl & 12,5 & 11,1 & 0,0 & 1,8 \\
\hline 7. & Cyperus rotundus L. & 10,4 & 2,2 & 0,0 & 1,8 \\
\hline 8. & Eriocaulon heterolepis Steud. & 0,0 & 0,0 & 0,0 & 3,6 \\
\hline 9. & Eupatorium odorata L. & 0,0 & 0,0 & 5,9 & 3,6 \\
\hline 10. & Fimbristylis acuminate Vahl & 0,0 & 0,0 & 5,9 & 0,0 \\
\hline 11. & Glinus lotoides L. & 0,0 & 11,1 & 0,0 & 0,0 \\
\hline 12. & Hedyotis corymbosa (L.) Lamk & 0,0 & 0,0 & 0,0 & 0,0 \\
\hline 13. & Hedyotis diffusa Wild & 14,6 & 4,4 & 0,0 & 12,5 \\
\hline 14. & Hyptis capitata Jacq & 20,8 & 11,1 & 47,1 & 30,4 \\
\hline 15. & Imperata cylindrica $\mathrm{L}$. & 0,0 & 2,2 & 0,0 & 0,0 \\
\hline 16. & Lindernia antipoda (L.) Alston & 4,2 & 0,0 & 0,0 & 0,0 \\
\hline 17. & Lindernia crustacea (L.) F.v.M. & 4,2 & 0,0 & 0,0 & 0,0 \\
\hline 18. & Lindernia sp. & 2,1 & 8,9 & 5,9 & 0,0 \\
\hline 19. & Ludwigia hyssopifolia (G.Don) Exell & 10,4 & 2,2 & 0,0 & 1,8 \\
\hline 20. & Ludwigia octovalvis (Jacq) Raven & 0,0 & 2,2 & 0,0 & 0,0 \\
\hline 21. & Paspalum conjugatum Berg & 2,1 & 2,2 & 0,0 & 0,0 \\
\hline 22. & Phyllanthus niruri (Auct) & 0,0 & 0,0 & 0,0 & 1,8 \\
\hline 23. & Scoparia dulcis L. & 4,2 & 2,2 & 5,9 & 0,0 \\
\hline 24. & Sonchus arvensis L. & 0,0 & 0,0 & 5,9 & 0,0 \\
\hline 25. & Torenia violacea (Azaola) Pennell & 0,0 & 0,0 & 0,0 & 0,0 \\
\hline & Total & 100 & 100,1 & 102 & 100,1 \\
\hline
\end{tabular}

Tabel 2. Nilai jumlah dominansi gulma pada umur 56 HST. 
Sedangkan NJD =Nilai penting/3. Jenis gulma yang mempunyai nilai NJD terbesar menunjukkan gulma tersebut dominan pada petak yang diamati.

Tinggi tanaman diukur pada umur 14, 28, 42 dan 56 HST. Pengukuran tinggi tanaman dimulai $5 \mathrm{~cm}$ dari permukaan tanah. Diameter batang tanaman diukur pada umur 14, 28, 42 dan 56 HST. Bobot Brangkasan (ton ha-1) serta peningkatan produksi tanaman jagung.

\section{Analisis Data}

Data hasil pengamatan terhadap tinggi tanaman dan diameter batang dianalisis menggunakan sidik ragam. Apabila terdapat perbedaan signifikan dilanjutkan dengan Uji Jarak Berganda Duncan (UJBD) pada taraf kepercayaan $95 \%$.

\section{HASIL DAN PEMBAHASAN}

Hasil Penelitian menunjukkan bahwa nilai dominansi gulma tertinggi secara berturut-turut pada perlakuan $\mathrm{A}_{0}$ adalah $B$. repens besar $51,5 \%, H$. capitata sebesar $18,2 \%, C$. rotundus serta Lindernia sp masing-masing sebesar 9,1\% (Tabel 1). Pada perlakuan $\mathrm{A}_{1}$ dominansi gulma tertinggi adalah Cyperus sp dan C. rotundus masing-masing sebesar 14,7\%, B. repens, C. kyllingia serta $H$. diffusa masingmasing sebesar $11,9 \%$. Pada perlakuan $\mathrm{A}_{2}$, dominansi gulma tertinggi adalah $C$. rotundus sebesar 22,2\% $H$. diffusa sebesar $15,6 \%$ serta $B$. repens dan Cyperus sp masing-masing sebesar 11,1\%. Pada perlakuan $A_{3}$, dominansi gulma tertinggi adalah C. rotundus sebesar 36,8\%, Cyperus sp sebesar $13,2 \%$ serta $H$. diffusa sebesar $11,8 \%$.

Perbedaan nilai jumlah dominansi gulma pada areal penelitian (Tabel 1; Tabel 2), ada hubungannya dengan keberadaan fungi mikoriza. Hal ini disebabkan adanya eksudat akar yang dihasilkan oleh gulma. Eksudat akar dari tumbuhan tertentu dapat merangsang pertumbuhan miselium fungi mikoriza. Menurut Manthey et al. (1994), secara umum kandungan eksudat akar antara lain adalah glukosa, fruktosa, asam organik, asam amino, lipida, vitamin, nukleotida, flavonoid, dan enzim. Dengan demikian, maka keragaman tumbuhan pada suatu areal tertentu dapat menentukan kuantitas dan kualitas eksudat yang tersedia pada perakaran. Miyasaka et al. (2003), mengemukakan bahwa rendahnya populasi fungi mikoriza di lapangan disebabkan oleh jenis-jenis gulma yang bersimbiosis maupun gulma yang tidak bersimbiosis dengan fungi mikoriza.

\section{Tinggi Tanaman Jagung}

Rata-rata tinggi tanaman jagung pada umur 14, 28, 42 dan 56 HST menunjukkan bahwa hasil pengamatan tinggi tanaman jagung tertinggi pada umur 14 HST diperoleh pada perlakuan $\mathrm{A}_{2}$ yang berbeda nyata dengan perlakuan $\mathrm{A}_{0}$ dan $\mathrm{A}_{1}$ tetapi

Tabel 3. Rata-rata tinggi tanaman jagung (cm) pada umur 14, 28, 42 dan 56 HST.

\begin{tabular}{|c|c|c|c|c|c|}
\hline \multirow{2}{*}{\multicolumn{2}{|c|}{ Perlakuan }} & \multicolumn{4}{|c|}{ Umur Tanaman (HST) } \\
\hline & & 14 & 28 & 42 & 56 \\
\hline Tanpa FMA $\left(\mathrm{A}_{0}\right)$ & & $20,62^{c}$ & $74,88^{\mathrm{d}}$ & $173,93^{d}$ & $182,14^{\mathrm{d}}$ \\
\hline FMA $15 \mathrm{~g} /$ lubang tanam $\left(\mathrm{A}_{1}\right)$ & & $25,74^{\mathrm{b}}$ & $85,43^{c}$ & $185,59 \mathrm{c}$ & $204,60^{c}$ \\
\hline FMA $30 \mathrm{~g} /$ lubang tanam $\left(\mathrm{A}_{2}\right)$ & & $28,34^{\mathrm{a}}$ & $90,85^{b}$ & $189,65^{b}$ & $221,53^{b}$ \\
\hline FMA $45 \mathrm{~g} /$ lubang tanam $\left(\mathrm{A}_{3}\right)$ & & $27,98^{\mathrm{a}}$ & $95,89^{a}$ & $194,98^{a}$ & $234,05^{\mathrm{a}}$ \\
\hline \multicolumn{6}{|l|}{ UJBD 95\% } \\
\hline & $2=$ & 1,112 & 4,030 & 1,547 & 5,128 \\
\hline & $3=$ & 1,149 & 4,169 & 1,601 & 5,305 \\
\hline & $4=$ & 1,168 & 4,239 & 1,627 & 5,394 \\
\hline
\end{tabular}

Ket.: Angka-angka yang diikuti dengan notasi huruf yang sama pada kolom yang sama, berbeda tidak nyata berdasarkan UJBD 95\%. 
berbeda tidak nyata terhadap perlakuan $\mathrm{A}_{3}$. Pada umur 28 HST tanaman jagung tertinggi diperoleh pada perlakuan $\mathrm{A}_{3}$ yang berbeda nyata dengan $\mathrm{A}_{0}$, $\mathrm{A}_{1}$ dan $\mathrm{A}_{2}$. Pada umur 42 HST tanaman jagung tertinggi diperoleh pada perlakuan $\mathrm{A}_{3}$ yang berbeda nyata dengan perlakuan $\mathrm{A}_{0}, \mathrm{~A}_{1}$ dan $\mathrm{A}_{2}$. Pada umur 56 HST tanaman jagung tertinggi diperoleh pada perlakuan $\mathrm{A}_{3}$ yang berbeda nyata dengan perlakuan $A_{0}, A_{1}$ dan $A_{2}$ (Tabel 3).

\section{Diameter Batang Tanaman Jagung}

Tabel 4 menunjukkan bahwa diameter batang tertinggi pada pengamatan umur 14 HST diperoleh pada perlakuan $\mathrm{A}_{3}$ yang berbeda nyata pada perlakuan $A_{0}, A_{1}$, dan $A_{2}$. Pada umur $28 \mathrm{HST}$ diameter batang tertinggi diperoleh pada perlakuan $\mathrm{A}_{3}$ yang berbeda nyata dengan perlakuan $A_{0}, A_{1}$ dan $A_{2}$. Pada umur 42 HST diameter batang tertinggi diperoleh pada perlakuan $\mathrm{A}_{3}$ yang berbeda nyata dengan perlakuan $\mathrm{A}_{0}, \mathrm{~A}_{1}$ dan $\mathrm{A}_{2}$. Pada umur 56 HST diameter batang tertinggi diperoleh pada perlakuan $\mathrm{A}_{3}$ yang berbeda nyata dengan perlakuan $\mathrm{A}_{0}$ dan $\mathrm{A}_{1}$ tetapi berbeda tidak nyata dengan perlakuan $\mathrm{A}_{2}$.

Berdasarkan hasil penelitian menunjukkan bahwa aplikasi FMA berpengaruh nyata terhadap tinggi tanaman dan diameter batang jagung pada umur 14, 28, 42, dan 56 HST. Tinggi tanaman dan diameter batang tanaman terbaik terdapat pada perlakuan FMA $45 \mathrm{~g} /$ lubang tanam masingmasing sebesar 234,05 $\mathrm{cm}$ dan 3,72 cm. Hal ini terjadi karena pada fase awal pertumbuhan tanaman, FMA sudah berinteraksi dengan akar tanaman jagung yang menyebabkan sistem perakaran dapat menyerap air dan unsur hara

Tabel 4. Rata-rata diameter batang (cm) pada umur 14, 28, 42 dan 56 HST.

\begin{tabular}{|c|c|c|c|c|c|}
\hline \multirow{2}{*}{ Perlakuan } & & \multicolumn{4}{|c|}{ Umur Tanaman (HST) } \\
\hline & & 14 & 28 & 42 & 56 \\
\hline Tanpa FMA $\left(\mathrm{A}_{0}\right)$ & & $0,23^{\mathrm{d}}$ & $1,29 c$ & $2,14^{\mathrm{d}}$ & $2,40^{c}$ \\
\hline FMA $15 \mathrm{~g} /$ lubang tanam $\left(\mathrm{A}_{1}\right)$ & & $0,28^{c}$ & $2,05^{b}$ & $2,40^{c}$ & $2,95^{b}$ \\
\hline FMA $30 \mathrm{~g} /$ lubang tanam $\left(\mathrm{A}_{2}\right)$ & & $0,34^{b}$ & $2,06^{b}$ & $2,56^{\mathrm{b}}$ & $3,46^{a}$ \\
\hline FMA $45 \mathrm{~g} /$ lubang tanam $\left(\mathrm{A}_{3}\right)$ & & $0,38^{a}$ & $2,20^{\mathrm{a}}$ & $3,37 \mathrm{a}$ & $3,72^{a}$ \\
\hline \multicolumn{6}{|l|}{ UJBD 95\% } \\
\hline & $2=$ & 0,027 & 0,058 & 0,132 & 0,298 \\
\hline & $3=$ & 0,028 & 0,060 & 0,137 & 0,309 \\
\hline & $4=$ & 0,028 & 0,061 & 0,139 & 0,314 \\
\hline
\end{tabular}

Ket.: Angka-angka yang diikuti dengan notasi huruf yang sama pada kolom yang sama, berbeda tidak nyata berdasarkan UJBD 95\%.

Tabel 5. Hasil Pengamatan terhadap Bobot Brangkasan Tanaman Jagung.

\begin{tabular}{cccc}
\hline Perlakuan & $\begin{array}{c}\text { Bobot sebelum } \\
\text { Dikonversi untuk 5 } \\
\text { Sampel Tanaman }(\mathrm{kg})\end{array}$ & $\begin{array}{c}\text { Bobot setelah } \\
\text { Dikonversi (ton } \\
\text { ha-1) }^{-1}\end{array}$ & $\begin{array}{c}\text { Rata-rata Peningkatan } \\
\text { Bobot Brangkasan } \\
\text { (ton ha-1) }\end{array}$ \\
\hline Tanpa FMA $\left(\mathrm{A}_{0}\right)$ & 1,38 & 4,42 & - \\
FMA 15 g/lubang tanam $\left(\mathrm{A}_{1}\right)$ & 2,31 & 7,39 & 2,97 \\
FMA 30 g/lubang tanam $\left(\mathrm{A}_{2}\right)$ & 2,31 & 7,39 & 2,97 \\
FMA 45 g/lubang tanam $\left(\mathrm{A}_{3}\right)$ & 2,49 & 7,96 & 3,54 \\
\hline \multicolumn{2}{c}{ Rata-rata peningkatan } \\
\hline
\end{tabular}


Tabel 6. Hasil Pengamatan terhadap Bobot Tongkol Berkelobot (ton ha-1).

\begin{tabular}{|c|c|c|c|c|c|c|c|}
\hline \multirow{3}{*}{ Perlakuan } & \multicolumn{7}{|c|}{ Bobot tongkol berkelobot (ton.ha-1) } \\
\hline & \multicolumn{7}{|c|}{ Tanaman sampel } \\
\hline & 1 & 2 & 3 & 4 & 5 & $\begin{array}{l}\text { Rata- } \\
\text { Rata }\end{array}$ & $\begin{array}{c}\text { Rerata } \\
\text { peningkatan } \\
\text { Produksi } \\
(\text { ton ha-1) }\end{array}$ \\
\hline \multirow[t]{2}{*}{ Tanpa FMA $\left(\mathrm{A}_{0}\right)$} & $0,39(\mathrm{x})$ & $0,32(\mathrm{x})$ & $0,34(x)$ & $0,36(x)$ & $0,32(x)$ & $0,35(x)$ & 2,86 \\
\hline & $6,20(\mathrm{y})$ & $5,10(\mathrm{y})$ & $5,40(y)$ & $5,80(y)$ & $5,10(y)$ & $5,50(y)$ & \\
\hline \multirow[t]{2}{*}{ FMA $15 \mathrm{~g} /$ lubang tanam $\left(\mathrm{A}_{1}\right)$} & $0,50(\mathrm{x})$ & $0,42(\mathrm{x})$ & $0,58(x)$ & $0,54(x)$ & $0,54(x)$ & $0,52(x)$ & 2,70 \\
\hline & $8,00(\mathrm{y})$ & $6,72(y)$ & $9,30(y)$ & $8,64(y)$ & $8,64(y)$ & $8,20(y)$ & \\
\hline \multirow[t]{2}{*}{ FMA $30 \mathrm{~g} /$ lubang tanam $\left(\mathrm{A}_{2}\right)$} & $0,50(\mathrm{x})$ & $0,50(\mathrm{x})$ & 0,64 (x) & $0,50(x)$ & $0,54(x)$ & $0,54(\mathrm{x})$ & 3,10 \\
\hline & $8,00(\mathrm{y})$ & $8,00(\mathrm{y})$ & $10,24(y)$ & $8,00(y)$ & $8,64(y)$ & $8,60(y)$ & \\
\hline \multirow[t]{2}{*}{ FMA $45 \mathrm{~g} /$ lubang tanam $\left(\mathrm{A}_{3}\right)$} & $0,46(\mathrm{x})$ & $0,50(\mathrm{x})$ & $0,56(x)$ & $0,52(x)$ & $0,54(x)$ & $0,52(x)$ & 2,80 \\
\hline & $7,36(\mathrm{y})$ & $8,00(y)$ & $8,96(y)$ & $8,32(y)$ & $8,64(y)$ & $8,30(y)$ & \\
\hline
\end{tabular}

Ket.: $(\mathrm{x})$ = nilai sebelum dikonversi $(\mathrm{kg}),(\mathrm{y})=$ nilai setelah dikonversi ke ha (ton ha ${ }^{-1}$ )

Tabel 7. Hasil pengamatan terhadap persentase kolonisasi fungi mikoriza pada perakaran tanaman jagung.

\begin{tabular}{ccccccc}
\hline \multirow{2}{*}{ Perlakuann } & \multicolumn{7}{c}{ Persentase kolonisasi fungi mikoriza $(\%)$} \\
\cline { 2 - 6 } & 1 & 2 & 3 & 4 & 5 & Rata-Rata \\
\hline $\mathrm{A}_{0}$ & 0 & 0 & 0 & 0 & 0 & 0 \\
$\mathrm{~A}_{1}$ & 80 & 60 & 90 & 80 & 90 & 80 \\
$\mathrm{~A}_{2}$ & 80 & 80 & 100 & 80 & 80 & 84 \\
$\mathrm{~A}_{3}$ & 70 & 80 & 80 & 80 & 80 & 94 \\
\hline
\end{tabular}

yang ada di dalam tanah. Husin (2000), menyatakan bahwa FMA dapat menghasilkan zat perangsang tumbuh di perakaran tanaman sehingga tanaman dapat tumbuh lebih baik dan tanaman tidak mudah stres ketika mendapat cekaman dari lingkungan dan tumbuhan lain.

\section{Bobot Brangkasan (ton ha-1)}

Berdasarkan Tabel 5, rata-rata peningkatan bobot brangkasan tanaman jagung berkisar antara 2,97-3,54 ton ha-1 atau dengan rata-rata kenaikan secara keseluruhan 3,16 ton ha-1. Perhitungan bobot brangkasan erat kaitannya dengan kebiasaan petani, di mana setelah panen brangkasan tanaman jagung selalu dijadikan sebagai sumber pakan hijauan ternak sapi. Jika mengacu pada rekomendasi yang dikeluarkan oleh Kartadisastra (1997), bahwa kebutuhan pakan ternak sapi per ekor per hari berkisar antara $30 \mathrm{~kg}$ $40 \mathrm{~kg}$, maka dengan hasil yang diperoleh pada penelitian ini bisa memberikan pakan pada ternak sapi sebanyak 1.000 ekor/hari pada setiap musim tanam. Tingginya brangkasan tanaman jagung yang dihasilkan diduga karena proses fotosintesis terjadi secara optimal yang berdampak pada tingginya akumulasi hasil fotosintat pada brangkasan tanaman tersebut.

\section{Peningkatan Produksi Tanaman Jagung}

Berdasarkan Tabel 6, terlihat bahwa rata-rata bobot tongkol berkelobot yang diberi perlakuan fungi mikoriza berkisar antara $8,20-8,60$ ton ha-1 dibandingkan dengan tanpa pemberian fungi mikoriza yaitu 5,50 ton ha-1. Hasil peningkatan produksi tanaman jagung yang diberi fungi mikoriza berkisar antara 2,70-3,10 ton ha-1 atau 
rata-rata peningkatan produksi tanaman jagung secara keseluruhan sebesar 2,86 ton ha-1.

\section{Persentase Kolonisasi Fungi Mikoriza}

Tabel 7 menunjukkan bahwa kolonisasi fungi mikoriza pada perakaran tanaman jagung berkisar antara $80-94 \%$ yang termasuk dalam kategori tinggi. Hal ini sebagai indikasi bahwa f u n g i mikoriza sangat aktif mengkolonisasi perakaran tanaman jagung. Tingginya kolonisasi fungi mikoriza pada perakaran tanaman jagung tersebut sangat erat kaitannya dengan keadaan tanah. Pada tanah-tanah marginal fungi mikoriza sangat efektif dalam membantu tanaman untuk menyerap unsur hara, khususnya hara P. Hasil analisis tanah pada lokasi penelitian menunjukkan $\mathrm{pH} 5,77$, bahan organik 1,92\%, nitrogen $0,17 \%$, fosfor 12,75 ppm serta kalium 0,22 me/100 g. Tinggi rendahnya kolonisasi fungi mikoriza pada akar akan menentukan kadar dan serapan hara $\mathrm{P}$ pada tanaman. Semakin tinggi kadar P dan bobot pupus kering tanaman, maka serapan $\mathrm{P}$ tanaman menjadi tinggi (Cottenie et al., 1982). Tingginya rata-rata serapan $\mathrm{P}$ tanaman erat kaitannya dengan kadar P dan bobot pupus kering tanaman (Manjunath \& Habte, 1990) serta produksi fotosintat berhubungan erat dengan serapan hara dan pertumbuhan tanaman (Azcon \& Ocampo, 1981).

\section{KESIMPULAN}

Berdasarkan hasil penelitian dapat disimpulkan bahwa aplikasi fungi mikoriza arbuskula sangat efektif dalam menekan pertumbuhan gulma, memperbaiki pertumbuhan dan produksi tanaman jagung. Secara umum peningkatan produksi tanaman jagung yang diberi fungi mikoriza berkisar antara 2,70-3,10 ton ha-1 atau rata-rata peningkatan produksi tanaman jagung secara keseluruhan sebesar 2,86 ton ha-1. Rata-rata persentase kolonisasi fungi mikoriza pada perakaran tanaman jagung tertinggi pada perlakuan FMA $45 \mathrm{~g} /$ lubang tanam $\left(A_{3}\right)$ sebesar $94 \%$.

\section{UCAPAN TERIMAKASIH}

Penulis menyampaikan ucapan terima kasih kepada Kementerian Riset, Teknologi dan Pendidikan Tinggi Republik Indonesia yang telah memberikan kepercayaan dalam memanfaatkan dana penelitian melalui skim Penelitian Terapan tahun 2018 dengan nomor Surat Perjanjian Pelaksanaan Penugasan Penelitian Nomor: SP DIPA-042.06.1.401516/2018, Tanggal 05 Desember 2017. Terima kasih pula disampaikan kepada Rektor Universitas Halu Oleo dan Ketua Lembaga Penelitian dan Pengabdian kepada Masyarakat Universitas Halu Oleo atas pelayanan administrasi yang prima.

\section{DAFTAR PUSTAKA}

Azcon, R., and J.A. Ocampo. 1981. Factors affecting the vesicular arbuscular infection and mycorrhizal dependency of thirteen wheat cultivars. New Pytol. 87: 677-685.

Betty, N.F., M.R. Setiwati dan R. Hindersah. 2002. Pengaruh pemberian pupuk organik dan aplikasi cendawan mikoriza terhadap populasi mikroba di rhizosfer, kolonisasi mikoriza, pertumbuhan dan hasil tanaman jagung pada Ultisol. Fakultas Pertanian. Universitas Padjadjaran. Bandung.

Chaves, R.C., and D.C. Bhadanari. 1982. Weed sampling and weed vegetation analysis. IRRI. Los Banos. Phillipines.

Cottenie, A., M. Verlo, L. Kiekens, G. Velghe and R.Camerlynck. 1982. Chemical analysis of plants and soil. Laboratory of Analytical and Agrochemistry. State University Ghent. Belgium.

Delvian. 2005. Respon Pertumbuhan dan perkembangan cendawan mikoriza arbuskula. USU Repository. Medan.

Delvian. 2006. Koleksi isolat cendawan mikoriza arbuskula asal hutan pantai. Jurusan Kehutanan Fakultas Pertanian Universitas Sumatera Utara. http://www.library.usu.ac.id/download/fp/06005280. pdf.

Halim, dan F.S. Rembon. 2013. Peningkatan produksi tanaman jagung berbasis bioteknologi mikoriza indigenous gulma. Laporan Hasil Penelitian Masterplan Percepatan dan Perluasan Pembangunan Ekonomi Indonesia (MP3EI-2011-2025). Lembaga Penelitian Universitas Halu Oleo. Kendari.

Halim, dan Resman. 2011. Domestikasi gulma penghasil biji sebagai media perbanyakan mikoriza indigen pada tanah marginal masam. Laporan Penelitian Hibah Bersaing. Lembaga Penelitian Universitas Halu Oleo Kendari. 
Halim. 2010. Kelimpahan populasi mikoriza indigen gulma pada hutan sekunder. Majalah Ilmiah Agriplus. 20(3): 194198.

Halim, F.S. Rembon, M.J. Arma, dan Resman. 2018. Penerapan dan pengembangan bioteknologi terpadu berbasis fungi mikoriza dan pupuk organik untuk meningkatkan produksi jagung dan kacang tanah pada lahan suboptimal. Laporan Penelitian Insinas Lembaga Penelitian dan Pengabdian kepada Masyarakat Universitas Halu Oleo. Kendari.

Halim, R. Hasid, and Mariadi. 2016. Improvement pepper plant seedling (Piper nigrum L.) of growth through the application of mycorrhiza fungi isolated from rootings of broad leaves weed. Australian Journal of Basic and Applied Sciences. 10(15): 155-159.

Halim. 2009. Peran endomikoriza indigenous gulma Imperata cylindrica (L) Beauv dan Eupatorium odorata (L.) terhadap kompetisi gulma dan tanaman jagung. Disertasi. Universitas Padjaajaran. Bandung.

Hartzler, B. and B. Pringnitz. 2005. Early season weed competition. Extension Weed Scientist and Extension Program Spesialist. Department of Agronomy. Iowa State University. http://www.ipm.institute. edu/ipm/icm/earlyweed.html. [di akses 20/9/2019].

Hayati, O.D.P., E. Prihastanti, dan E.D. Hastuti. 2019. Kombinasi pupuk nanosilika dan NPK untuk peningkatan pertumbuhan tanaman jagung (Zea mays L. var pioneer 21). Jurnal Biologi Papua. 11(2): 94-102.

Husin, E.F. 2000. Cendawan mikoriza arbuskula. Fakultas Pertanian Universitas Andalas. Sumatera Barat.

Kartadisastra, H.R. 1997. Penyediaan E pengelolaan pakan ternak ruminansia (Sapi, Kerbau, Domba, Kambing). Kanisius.
Yogyakarta.

Manjunath, A. and M. Habte. 1990. Establishment of soil solution $\mathrm{P}$ levels for studies involving vesicular arbuscular myccorhizal symbiosis. Commun. Soil Sci. Anal. 21: 537-566.

Manthey, J.A., D.E. Crowley, and D.G. Luster. 1994. Biochemistry of metal micronutrients in the Rhizosphere. CRC Press.

Miyasaka, S.S., M. Habte, J.B. Friday and E.V. Johnson. 2003. Manual on arbuscular mycorrhizal fungus production and inoculation techniques. Cooperative Extension Service.College of Tropical Agriculture and Human Resource. University of Hawaii. Manoa. http:/ / www.ctahr.hawaii.edu.

Nugroho, B. 2009. Budidaya tanaman jagung. Gramedia Pustaka Utama. Jakarta.

Santoso, E. 2007. Aplikasi mikoriza untuk meningkatkan kegiatan rehabilitasi hutan dan lahan terdegradasi. Prosiding Ekspose Hasil-Hasil Penelitian. Padang. Hlm: 71-80.

Setiadi, Y. 1996. Mengenal cendawan mikoriza arbuskula (CMA) dan prospek aplikasi sebagai pupuk biologis untuk meningkatkan pertumbuhan dan kualitas semai tanaman perkebunan. Makalah Disampaikan dalam Rangka Lokakarya Sistem Produksi Bibit secara Massal. Bogor.

Subowo, Prihatin, dan T.A Kentjanasari. 1996. Pemanfaatan Biofertilizer untuk Meningkatkan Produktivitas Lahan Pertanian. Jurnal Litbang Pertanian. 15 (1): 22-31.

Talanca, H. 2010. Status Cendawan Mikoriza VesikularArbuskular (MVA) pada Tanaman. Prosiding Pekan Serealia Naional.Sulawesi Selatan. 353-357. 